Laboratory of Economics and Management Sant'Anna School of Advanced Studies

Piazza Martiri della Libertà, 33 - 56127 PISA (Italy)

Tel. +39-050-883-343 Fax +39-050-883-344

Email: lem@sssup.it Web Page: http://www.lem.sssup.it/

\title{
LEM
}

Working Paper Series

\section{Intellectual Property Rights and Market Dynamics}

Fabrizio CESARONI*t

Paola GIURI*

* Sant'Anna School of Advanced Studies

${ }^{*}$ University of Lecce 


\title{
Intellectual Property Rights and Market Dynamics
}

\author{
Fabrizio Cesaroni*, Paola Giuri ${ }^{\circ}$ \\ *University of Lecce and Sant'Anna School of Advanced Studies, Pisa \\ ${ }^{\circ}$ Sant'Anna School of Advanced Studies, Pisa
}

\section{Introduction}

The modern economy is currently characterised by some emerging phenomena related to the protection of intellectual property. First, technologies are increasingly bought and sold in the market, mostly in sectors in which patent protection is relevant and strong enough. Second, the open science model is more and more diffused in the technology development process of business sectors like (open source) software. Third, scientific discoveries of academic researchers, traditionally diffused in an open science system, are increasingly protected through intellectual property rights and specifically patents.

These phenomena highlight that two contrasting models - i.e. the strong intellectual property rights (IPR) model, and the open science model - are currently diffusing in the technological and economic environment, and shaping in opposite ways the behaviour of different institutional agents and organisations. These two models have been analysed in the economic and policy literature. They have traditionally been applied to alternative institutional contexts. The strong IPR model has been associated to the business environment, while the open science model has been associated to the academic or research system. Nevertheless, more recently, a strengthening of the IPR system has occurred in the public research system, and open science models have been adopted in private sectors like the open source software.

This paper discusses these different models of intellectual property protection and their implications on the innovative activity of firms and economies and the market dynamics. The IPR and the open science models present advantages and drawbacks in terms of incentives to innovate, adoption of technological innovations, and diffusion of technologies in different institutions (large and small firms, public research institutions) and different sectors. This paper identifies several policy issues related to the conditions under which the two models can be sustainable and beneficial for the economy.

Under the strong IPR model, scientific and technological knowledge is protected by exclusive rights (such as patents) granted to the inventors. The public authority of the country where the inventor has applied for its invention ensures the enforcement of the property right. In return for such a protection, information on the invention have to be publicly disclosed, in order to 
enrich the total body of technical knowledge in the world. Such an ever-increasing body of public knowledge promotes further creativity and innovation from others actors. This model creates strong and direct incentives to innovate, as the owner of the property right retains all the possible returns from an innovation. Either in the case in which the innovation is used inhouse to produce products or services to be sold in the final market, or in the case in which the new (scientific and technological) knowledge is sold to downstream users in the market for technologies (Arora et al., 2001), this model prevents freely available knowledge spillovers to be generated. Returns from new scientific and technological knowledge are completely privatised at all different stages of technology and product development.

By contrast, under the open science model, inventors are not granted any right for their inventions, nor those who use the same inventions for subsequent developments. New scientific and technological knowledge is freely available to anyone in the public domain. While the original knowledge cannot be used on an exclusive base, specific applications of the same knowledge can be privatised, in some cases. According to this model, new knowledge diffuses more rapidly among agents. Inventors do not extract any direct gain from the new knowledge, but only indirect incentives. On the one hand, their public reputation increases. On the other, and in the long run, they can gain profits from further developments or applications of the original knowledge or from career development. This model is typical of the academic research (Dasgupta and David, 1994), and partly of the software industry (Lerner and Tirole, 2002a and 2004; Gambardella and Hall, 2005). From a social point of view, this model maximises the social returns from innovations, but requires some forms of co-ordination among independent agents. Absent any co-ordination, individual agents might behave as free riders and privatise the public knowledge.

Both models present advantages and disadvantages from a private and a public perspective. In some cases, the two models simultaneously operate. A first case is the software industry, where open source software is simultaneously made available with products based on proprietary software (i.e. software protected through copyright and without disclosing the source code) or patented software. A second case is the university system, where open science is the predominant model of knowledge production and diffusion, but patenting and licensing of the outcomes of the research is more and more diffused. In both cases, all the relevant issues have not been completely assessed and discussed yet, and policy implications have not beet fully explored.

Against this background, this paper focuses on some key and emerging issues on intellectual property protection, and discusses potential implications of the strength or openness of IPRs on the market dynamics. Specifically, the study examines the effects of (stronger or weaker) patent protection on large and small firms, and on entry and growth of new technology-based firms. Strengths and weaknesses of both strong IPRs and open science models are then analysed and discussed.

The paper is organised as follows. Section 2 provides a brief introduction on recent trends in intellectual property protection in US and Europe. Sections 3 discusses a few emerging issues associated to the strong IPRs system: the development of markets for technologies, the use or not use of patents, the patenting of upstream inputs like research tools, the increasing usage of litigation and the corresponding (social) costs. Section 4 analyses the system of open science, and specifically considers the case of software and the co-existence of patenting and open science in the software sector (open source software). Section 5 concludes and discusses some policy implications. 


\section{Recent trends in intellectual property protection: institutional changes and empirical evidence}

In the last two decades, the system of intellectual property protection has witnessed a few crucial institutional transformations ${ }^{1}$. At the same time, patenting trends in different countries and technologies and the patenting behaviour of different types of inventive actors have changed. In essence, several empirical evidences point up an intensification of the patent activities, with differential rates of growth across patent systems, countries, technologies and actors.

The main empirical fact that has attracted the interest of several scholars is the unprecedented growth in the demand for protection of intellectual property observed during the 1980s and the 1990s. The number of US patent applications has grown from a range of 40-80,000 in the 1980 s to at least 120,000 patents in 1995 (Kortum and Lerner, 1999) ${ }^{2}$. This discontinuity has also been examined by Hall (2004), who has shown a structural break in the time series of the growth of the number of patents in the mid-1980s. The growth rate of the number of patents boosted from an average of $0.3 \%$ before the break in 1984 to an average of $6.9 \%$ after 1984 . At the country level, the largest explosion in the patent activity is observed for US inventors at the US Patent and Trademark Office (USPTO) and in other Patent Offices, while a similar upturn is not registered for European or Japanese inventors. In Europe the rate of growth in the 1980s is evident but is not as pronounced as in the United States, while in Japan the rates of growth have been marked already since the 1970s.

In some technologies, like biotechnology and software, the patenting activity intensified more than the average, bus in absolute terms the impact on the total growth has been limited (Kortum and Lerner, 1999). Hall (2004) has also demonstrated that the intensification of patenting activities has not been specific to some technologies, but to some sectors (i.e. the electrical, electronics, computing and scientific instrument sectors). When looking at the applicant level, it is also worth noting that the growth rate of patents for new patenters has resulted larger that the growth rate of patents by incumbent patenters (Kortum and Lerner, 1999).

During the 1980s and the 1990s the patent system has also witnessed some important institutional changes, which have contributed to the strengthening of patent protection. First, in 1982 the creation of a unified Court of Appeals for the Federal Circuit (CAFC) for patent settlements in the US replaced the courts of appeal in local circuits. This decision marked a "pro-patent" behaviour of the courts (Mazzoleni and Nelson, 1998; Kortum and Lerner, 1999; Jaffe, 2000; Hall and Ziedonis, 2001), as desired by many of its advocates (Granstrand, 2005). Kortum and Lerner (1999) have reported that before the creation of CAFC (between 1953 and 1978 ) only $62 \%$ of decisions were in favour of the patent holders, while this share has increased to $90 \%$ after the creation of the CAFC (from 1982 to 1990). The reversing of decisions of invalidity or non-infringements also increased from $12 \%$ pre-CAFC to $28 \%$ postCAFC. Moreover, in some court decisions concerning patent suits the amount of damages to be paid for infringement has been strikingly high. Rivette and Kline (2000) report that Kodak had to pay, after the infringement of Polaroid's patents on instantaneous camera, \$925 million of damages to Polaroid, \$ 100 million of legal fees for a 14-year long battle. Kodak was also forced to close a plant of $\$ 1,5$ billion, to fire 700 employees and finally to spend $\$$ 500 million to buy-back 16 million cameras sold in 10 years. This accounted for a total of

\footnotetext{
${ }^{1}$ For a long term historical account of the evolution and diffusion of the patent system see Granstrand (2005).

${ }^{2}$ For a longer-term evolution of the patent activities see Lerner (2002).
} 
more than $\$ 3$ billions. In another settlement in 1991, Minolta had to pay $\$ 127.5$ million to Honeywell for having used a patent, even though not used by Honeywell (Rivette and Kline, 2000). Nevertheless, the effects of CAFC were not immediate after its formation. The impact of CAFC on the favourable legal treatment of patent rights in US courts was not widely publicized until the mid-1980s. During this period, a series of business press articles appeared, and diffused a common sense on strengthening of patent protection (Forbes, 1985 and 1986; Fortune, 1986).

Second, at the international level, the TRIPS agreement of 1994 represented another hallway of the pro-patent era. It focused on the setting of international standard for IP protection, assisting particularly the interests of multinational corporations for a stronger international intellectual property protection, but also engendering higher barriers for developing countries (Granstrand, 2005).

Finally, in 1980 the Bayh-Dole Patent and Trademark Amendment Act was adopted. By substituting the specific Institutional Patent Agreements that universities were obliged to set with federal agencies, the new Act allowed unlimited patenting and exclusive licensing of results of federally funded research, and made easier these activities (Mowery et al., 2004). The Bayh-Dole Act contributed to a stronger protection of the intellectual property, by providing incentives to increasingly protect research outputs to institutions traditionally producing knowledge made freely available in the public domain. Mowery and Sampat (2005) illustrate that the share of US university patents on all US domestic patents has increased from less than $1 \%$ at the end of the 1970 s to more than $3.5 \%$ at the end of the 1990s. However, they report that there is no evidence of a change in the patent propensity over time (relative to R\&D). A large portion of the growth of the share of US university patents is covered by biomedical patents, due to the expanded opportunities for commercial applications of patents in the related technological fields. Thursby and Thursby (2003) also report some data from the 1991 and 2000 surveys of Association of University Technology Managers (AUTM, 1999 and 2001) showing that after the Bayh-Dole Act there has been a remarkable growth of the number of inventions disclosed (84\%), number of patent applications $(238 \%)$, licensing agreements $(161 \%)$ and royalties from licensing agreements (520\%). Furthermore, after the Bayh-Dole Act, also Japan and some European countries introduced legislations ruling the transfer of intellectual property rights to individual researchers or to the institutions with the aim of improving the technology transfer from university to industry.

An additional reinforcement of the IPR system derives from the expansion of the range of admitted subject matters for patenting undergone in the last two decades. Several authors have reported court decisions of validity of patents covering inventions previously non patentable, like biotechnologies, software and business methods (Cohen and Lemley, 2001; Gallini, 2002; Bessen and Hunt, 2004; Hall, 2003; Graham and Mowery, 2003). In 1980 the decision Diamomd vs. Chakrabarty allowed the patentability of genetically engineered bacteria. With the Diamond vs Diehr dispute in 1981 software began to be patentable. Finally, the State Street Bank and Trust vs. Signature Financial Group in 1998 opened the patentability of business methods.

Bessen and Hunt (2004) documented a continuous growth in the number of software patents in the US during the last 25 years. The share on the total patents has also jumped from $1.1 \%$ in 1976 to $5.2 \%$ in 1990 and to $14.9 \%$ in 2002. The software sector has also been characterised by the emergence of the open source model of software development, characterised by disclosure and sharing of innovations (Lerner and Tirole, 2002a). However, the future sustainability of both models and the effects on the rate of patenting or increasing disclosure is still unclear. Issues concerning software will be better explored in Section 4. 


\section{The effects of strong IPRs on large and small (technology-based) firms}

Subsequently to the changes in the patent environment described in the previous section, the economic and managerial literature has started to debate on the reasons for the explosion of patenting activities by different actors (large and small firms, public research institutions, new firms), and on the effects of the strengthening of the patent system on the incentives to innovate by large and small firms, the diffusion of knowledge and the pace of technical progress, and the incentives to invest in the development of second generation technologies.

Among the benefits of a strong IPR system, the mostly cited (and commonly accepted) is that it encourages the entry of new firms and the commercialisation of technologies. Firms specialised in the supply of technology-based components but without downstream manufacturing facilities have no alternative means for protecting their technological assets and earn profits from them - other then IPRs. Especially to these firms, but also to larger manufacturing firms involved in technology trade, a system of strong and enforceable IPRs is a necessary condition for their business model. Therefore, strong IPRs allow markets for technology to operate, and encourage the division of innovative labour among independent firms and the entry of specialised technology producers.

At the same time, an increased patent protection is also associated to potential costs. First, in the case of cumulative, complex technologies, if intellectual property rights are assigned to several developers of technological components, the integration of these components in the complex product might be difficult, or at least result in an increase of transaction costs. Hence, an excessive fragmentation of property rights is often associated to the so-called "tragedy of anti-commons". Second, strong IPRs might induce firms to protect with patents a larger fraction of technologies, even those technologies that are not actually used in any existing product (sleeping patents), or whose only purpose is to avoid competitors to explore specific technological trajectories (blocking patents). Indeed, stronger IPRs are often associated to a larger share of unused patented technologies. Third, as exposed in the previous section, the pro-patent era has put another actor into the patenting arena: universities. The direct consequence of their aptitude towards patenting is that the (scientific and technological) knowledge that was previously available for free is now traded in the market for technology. Finally, stronger IPRs are also associated with increasing costs of litigations. Apart from the financial resources spent in patent suits and settlements, the most relevant indirect effect is that increased litigation costs reduce the incentives to innovate especially for new and small firms for which the costs of a suit may be unaffordable. As a consequence, from a social point of view, litigations often result in a transfer of resources from small to large firms.

We discuss these issues more extensively in the following sections. Our aim is to provide theoretical and empirical evidence of the benefits and costs associated with a system of strong IPRs. Furthermore, we aim at discussing the effects of such benefits and costs on both large incumbent firms, and small technology-based new entrants.

\subsection{IPRs and markets for technology}

One of the commonly accepted implications of the existence of (strong) property rights is that they allow technologies and technological knowledge to be exchanged and traded in specialised markets for technology. The functioning of such markets has been empirically documented for several high-tech industries, like chemicals, biopharmaceuticals, software, semiconductors and electronics. The number of technology transactions amongst independent organizations has constantly grown especially during the 1990s (Arora et al., 2001), even 
though the presence of an active market for technology during the late nineteenth and twentieth centuries has been documented as well in the American glass industry (Lamoreaux and Sokoloff, 1997 and 1999).

In the chemical processing industry, an upstream sector of independent technology suppliers has emerged since the switch to petrochemicals after the Second World War (Freeman, 1968; Arora and Gambardella, 1998). New specialised suppliers - the so-called specialised engineering firms (SEFs) - have appeared and have started to diffusely license process technologies to downstream chemical companies in the developed countries, and later in the less developed countries. The market for process technologies in chemicals, however, has been also operated by large chemical corporations, which have been (and still are) involved in licensing their proprietary technologies to smaller chemical and non-chemical firms (Cesaroni and Mariani, 2001; Cesaroni, 2003). Similarly, in the biopharmaceutical industry, a division of innovative labour between new research-intense biotechnology firms and large drug manufacturers has been particularly pronounced during the 1990s and nowadays (Cockburn et al., 1999). Licensing contracts are the preferred way that specialised suppliers use to provide pharmaceutical companies with new chemical compounds, research services, or research tools like software programs for drug research, testing, etc. (Red Herring, 1998). Finally, in the semiconductors and electronics industries, licensing and cross-licensing contracts are a common solution that established firms adopt in order to obtain the rights to use technological components owned by several and dispersed firms for the development of complex products (Grindley and Teece, 1997).

The key point of these findings is that the functioning of such markets for technology is strictly linked to the existence of patents and an efficient system of protection of intellectual property rights. On the one hand, the possibility to protect part of a technology with one or more patents allows the same technology to be licensed to third parties. In situations in which a technology holder enters into a licensing agreement with a potential buyer or licensee, the information disclosed from the former can be used by the latter to invent around (Gallini, 1992). However, if patents protect the codified component of the technology, the possibility to invent around declines. The stronger the patent protection, the greater the cost of inventing around, and hence the higher is the potential advantage arising from licensing. The chemical industry provides a clear example in this respect (Arora, 1995 and 1997).

On the other hand, markets for technology are operated either by large corporations with unused patents in their patent portfolios, or by specialised technology suppliers that use patents to protect their core technological assets. In the first case, markets for technologies represent an additional option available to large firms in order to exploit (sell or license) existing unused patent-protected technologies. Usually, firms tend to protect with patents more technologies than the amount they actually use in their core business operations. Apart from processes of technological diversification, unused patents have a strategic motivation (sleeping patents, strategic delays, etc.) (Cohen, Nelson and Walsh, 2000). These patents can be used for blocking innovative activity of rivals, or just because technologies and products based on such technologies are not completely developed. As a matter of fact, the share of unused patents in the portfolios of large corporations might be relevant. A recent survey (European Commission, 2005) provides evidence on the use and value of more than 9,000 European (EPO) patents of inventors in six European countries (France, Germany, Italy, Netherlands, Spain and United Kingdom). Results from this survey (Table 1) show that the share of patents (not) used both to prevent competitors to invest in specific technological areas (i.e. blocking patents), or to wait for future uses (i.e. sleeping patents), ranges from about $18 \%$, in the case of small companies, to $40 \%$, in the case of large firms and universities. The share of unused patents is almost $45 \%$ in other public research organisations. Obviously, 
these results reflect differences in missions and goals of the institutions, but also show that the lost of potential benefits due to unused patented technologies might be a severe concern for the economy on the whole.

Table 1 - Share of patents actually used economically by type of inventors' employer

\begin{tabular}{|l|cccccc|c|}
\hline & $\begin{array}{c}\text { Licensing } \\
\text { Only }\end{array}$ & $\begin{array}{c}\text { Licensing } \\
\text { \& Used }\end{array}$ & $\begin{array}{c}\text { Cross- } \\
\text { Licensing }\end{array}$ & Used Only & $\begin{array}{c}\text { Blocking } \\
\text { (unused) }\end{array}$ & $\begin{array}{c}\text { Sleeping } \\
\text { (unused) }\end{array}$ & Total \\
\hline Large Firms & $3.03 \%$ & $3.22 \%$ & $3.03 \%$ & $49.93 \%$ & $21.72 \%$ & $19.06 \%$ & $100.00 \%$ \\
Medium Firms & $5.38 \%$ & $3.59 \%$ & $1.20 \%$ & $65.62 \%$ & $13.90 \%$ & $10.31 \%$ & $100.00 \%$ \\
Small Firm & $14.97 \%$ & $6.90 \%$ & $3.89 \%$ & $55.78 \%$ & $9.62 \%$ & $8.84 \%$ & $100.00 \%$ \\
Hospitals, Foundations, & $35.42 \%$ & $6.25 \%$ & $0.00 \%$ & $16.67 \%$ & $18.75 \%$ & $22.92 \%$ & $100.00 \%$ \\
Private Research Org. & $23.19 \%$ & $5.80 \%$ & $4.35 \%$ & $21.74 \%$ & $10.87 \%$ & $34.06 \%$ & $100.00 \%$ \\
Public Research Org. & $22.50 \%$ & $5.00 \%$ & $5.00 \%$ & $26.25 \%$ & $13.75 \%$ & $27.50 \%$ & $100.00 \%$ \\
Universities \& Education & $16.67 \%$ & $8.33 \%$ & $0.00 \%$ & $41.67 \%$ & $8.33 \%$ & $25.00 \%$ & $100.00 \%$ \\
Other Government Org. & $17.02 \%$ & $8.51 \%$ & $4.26 \%$ & $34.04 \%$ & $12.77 \%$ & $23.40 \%$ & $100.00 \%$ \\
Other & $6.17 \%$ & $3.92 \%$ & $3.06 \%$ & $50.53 \%$ & $18.83 \%$ & $17.50 \%$ & $100.00 \%$ \\
Total & & & & & & &
\end{tabular}

Source: European Commission (2005), Patval Survey.

In some cases, however, firms might be willing to sell these unused technologies to other firms. In an often cited survey conducted over European, North American and Japanese firms (BTG, 1998), it has been documented that unused technologies, which would have a commercial value if they were sold or licensed, amount to more than $30 \%$ of patent portfolios of the surveyed firms. Furthermore, nearly two-thirds of such organisations have a share of unutilised patents, and one in eight have in excess more than 1,000 patents. Most of them find licensing out attractive, primarily because of potential financial, economic or commercial benefits.

Examples of firms that have started to license their unused patent-protected technologies can be found in several industries. For instance, in chemicals, British Petroleum, Union Carbide, and many others have been particularly active in licensing (Grindley and Nickerson, 1996; Arora et al., 2001). In electronics and semiconductors, IBM has earned almost \$ 1 billion in 1998 by licensing its patents (Rivette and Kline, 1999), and Texas Instruments has earned royalties of almost $\$ 1.8$ billion during a five-year period (Grindley and Teece, 1997). In general, many other large corporations from different industries have started to sell their patent-protected technologies. Some of these companies, such as Boeing, Monsanto, Philips, Procter \& Gamble, have also used virtual marketplaces (e.g., "yet2.com"). ${ }^{3}$

Apart from large corporations, the most relevant evidence of how patent protection can allow firms to enter the market for technologies is that of small technology suppliers.

Table 1 shows that small firms licence almost $26 \%$ of their patents (including patents that are only licensed, patents that are simultaneously licensed and internally used, and cross-licensed patents). This share is only about $9 \%$ for large firms and $11 \%$ for medium firms (100-250 employees). The share of licensed patents is the largest for universities and other research

\footnotetext{
${ }^{3}$ See http://www.yet2.com.
} 
organisations. It is also worth noting that small firms use about $15 \%$ of their patents "only" for licensing agreements, against $3 \%$ for large firms.

The core business of small technology-based firms is in fact to develop new technologies (or new technological components) to be sold to other firms placed downstream in the value chain. They are not directly involved in manufacturing or marketing, and hence lack appropriate complementary assets needed to exploit their technological competences (Teece, 1986). However, if they can protect their technologies with patents, and if patents are strong enough to prevent risks of infringement or to be invented around, such small technology suppliers can trade their technologies and overcome the lack of complementary assets (Arora et al., 2001).

In other words, strong patents are critical to encourage vertically specialized suppliers enter the market, because appropriate contracts for the exchange of technology and related tacit know-how can be defined. In relative terms, the value of patent protection to these firms is higher than to large established technology holders, which have the capabilities to protect their innovations with alternative means, and compete in the market for products. As demonstrated by Arora and Fosfuri (2003), the presence of a firm in the market for products and the level of competition in this market affect her incentives to licence technologies to other firms wishing to enter into the same product market. In this case, a revenue effect - i.e. the increase in revenues coming from the licensing fees - and a rent dissipation effect - i.e. the reduction of revenues deriving from the increased competition in the product market - are compared. If a firm is a monopolist in the product market she will have no incentives to license her technologies, because the rent dissipation effect will never be compensated by incoming licensing fees. By contrast, if there are other competitors in the product market, the rent dissipation effect will be shared across all competitors. The effect on each firm will be marginal, and this will increase each firm's incentive to license. On the other hand, small firms missing the complementary production and commercialisation capabilities and with no share in the product market have the maximum incentives to license their technologies.

Contrarily to large companies, small independent technology suppliers have no alternative possibilities to protect their technologies and appropriate the benefits of their innovations other than by means of patent protection. In turn, the existence of a system of strong intellectual property rights enhances the incentives to innovate of the specialised technology suppliers compared to established companies. As a consequence, entry of such firms into the market for technologies should be facilitated. Empirical evidence in the cases of biopharmaceuticals (Cockburn et al., 1999), chemicals (Arora and Gambardella, 1998), and environmental technologies (Arduini and Cesaroni, 2004) shows that entry in such industries has been characterised by similar dynamics.

Hence, from an industry perspective, strong IPRs not only determine an increase in the overall level of investments in R\&D and innovations, but also contribute to the locus of innovative activities (Arora and Merges, 2004). By allowing the upsurge of smaller independent suppliers, strong IPRs contribute to the "dis-integration" of industry structures, and to an increasing division of innovative labour at the industry level. Consequently, the number of integrated, Chandlerian large firms should reduce accordingly.

\section{Universities as suppliers of upstream inputs}

Similarly to small independent technology suppliers, whose entry into the market for technology has been facilitated by the strengthening of IPRs, universities (and other Public Research Organisations - PROs) can be considered a second, relevant actor of such a market. 
Similarly to small technology suppliers, their entry into the market has been allowed by the possibility to protect with patents their research results.

University patenting is not a new phenomenon. In the US, universities and other publicly funded research laboratories have been active in patenting for a long time, since the earliest years of the twentieth century (Mowery and Sampat, 2001). However, since the late 1980s, the number of patents from PROs has significantly increased (Jaffe, 2000; Carlsson and Frihd, 2000). Recent data of the National Science Foundation (NSF, 2004) report an escalation of the annual number of university patents from less than 500 in the early 1980 s to more than 3,000 in the late 1990s (Figure 1). As recalled in previous sections, the change in the institutional framework that has taken place in the US during the 1980s, with the introduction of the Bayh-Dole Act, has been the main driver of this phenomenon. Accordingly, many universities have modified their mission and their organisations. Specific Technology Transfer Offices have been created, with the explicit aim of promoting effective licensing of patented technologies. The successful example of the University of Columbia is a representative case in point (Mowery and Sampat, 2001).

Figure 1 - University patenting in the US, 1982-1998

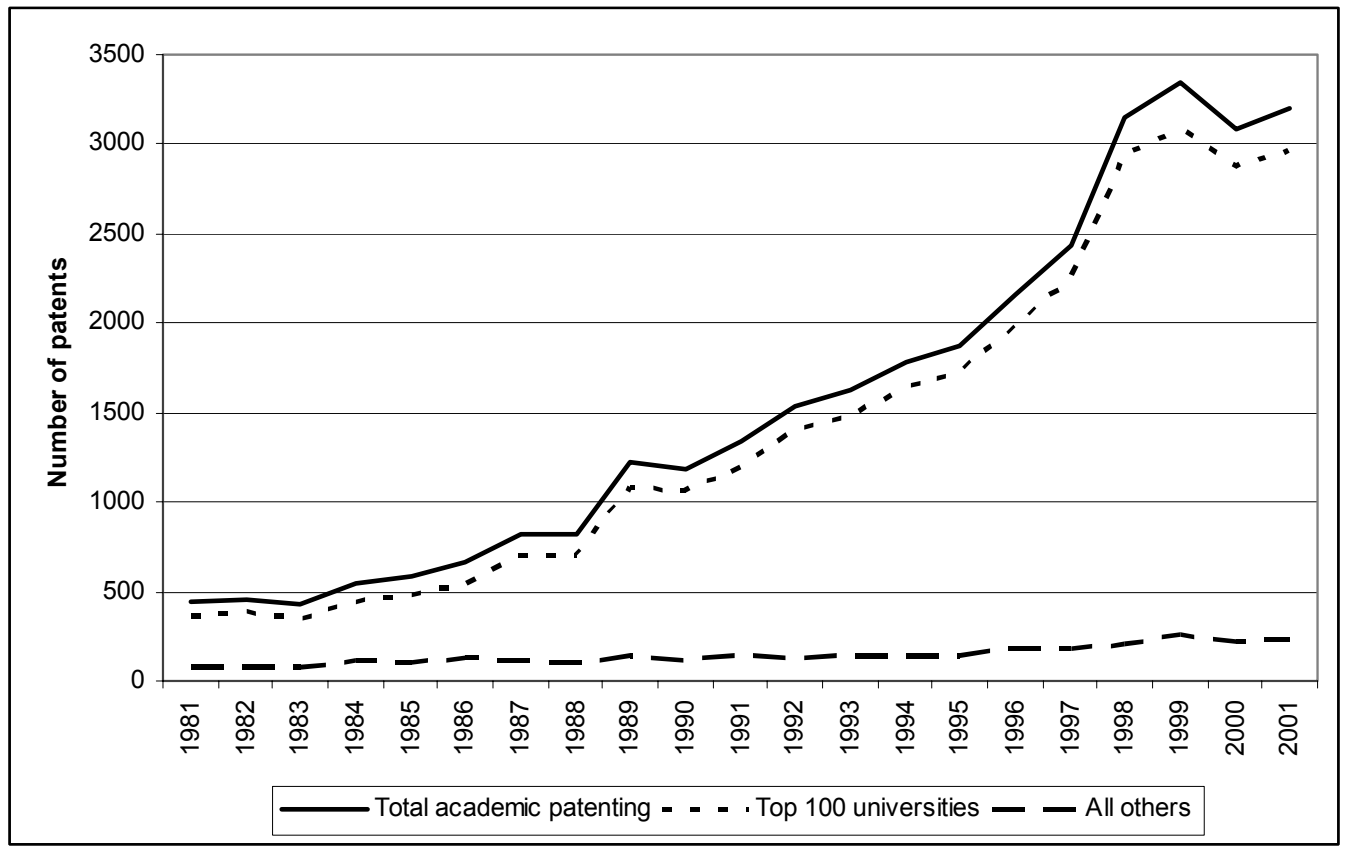

Source: NSF (2004).

As a matter of fact, following the adoption of the Bayh-Dole Act, many universities have started to protect the results of their research activity with patents, and to assign exclusive and non-exclusive licenses to private companies. While the broad diffusion of research results was (one of) the main concerns of public research organisations, and a general objective of their mission, with the advent of university patenting the diffusion of knowledge from university to the industry has been subject to additional barriers. Especially in those scientific fields - such as biomedical and genetic research - where results of scientific research have immediate technological (and commercial) applications, universities have used patents in order to extract the maximum value from them (Mowery et al., 2001). Some of them have considered the possibility to license their patent-protected research results as an additional source of funds, 
capable of balancing the reduction of funds from governments and national agencies. In so doing, they have become active in the market for technologies.

As Table 1 revealed for the case of EPO patents of European inventors, compared to other institutional actors, universities and public research organisations have the second largest share of patents of respective patent portfolios licensed to other organisations. In general, universities and public research organisations are more involved in patent licensing than industrial firms (European Commission, 2005). Table 2 also reports the average level of importance (on a scale 1 to 5) of different reasons for patenting by type of institution. Licensing is considered relatively more important for universities and PROs than for firms. Prevention from imitation and blocking patents is not an important reason for patenting by universities and PROs, while only these actors consider reputation quite important.

Table 2 - Reasons for patenting by type of inventors' employer

\begin{tabular}{|l|cccccc|}
\hline & $\begin{array}{c}\text { Commercial } \\
\text { exploitation }\end{array}$ & Licensing & Cross-licensing & $\begin{array}{c}\text { Prevention from } \\
\text { imitation }\end{array}$ & Blocking patents & Reputation \\
\hline Large Firms & 3.76 & 1.96 & 1.96 & 3.85 & 3.08 & 2.26 \\
Medium Firms & 3.91 & 1.76 & 1.35 & 3.87 & 3.09 & 2.14 \\
Small Firm & 4.03 & 2.26 & 1.32 & 3.66 & 2.87 & 2.14 \\
Hospitals, Foundations, & 3.65 & 3.58 & 1.25 & 3.27 & 2.58 & 2.44 \\
Private Research Org. & 3.05 & 3.00 & 1.54 & 2.86 & 2.05 & 2.91 \\
Public Research Org. & 3.48 & 3.15 & 1.59 & 2.85 & 2.42 & 2.94 \\
Universities \& Education & 2.54 & 2.77 & 1.15 & 2.38 & 2.15 & 1.23 \\
Other Government Org. & 3.39 & 2.8 & 1.74 & 3.46 & 2.54 & 1.89 \\
Other & 3.78 & 2.06 & 1.79 & 3.76 & 3.01 & 2.27 \\
\hline Total & & & & & \\
\hline
\end{tabular}

Source: European Commission (2005), Patval Survey.

Interestingly, once excluded the peculiar case of individual innovators (i.e. innovators who are not employees of any private or public institution), the survey of the European Commission (2005) reports that universities are also the most active institution to use their patents to create new companies, typically through processes of spin-offs creation (Figure 2). Taken together, these two figures confirm how, contrarily to firms involved in manufacturing and product commercialisation, universities use patents through external exploitation processes. 
Figure 2 - Share of patents that give rise to the creation of new firms by type of applicant

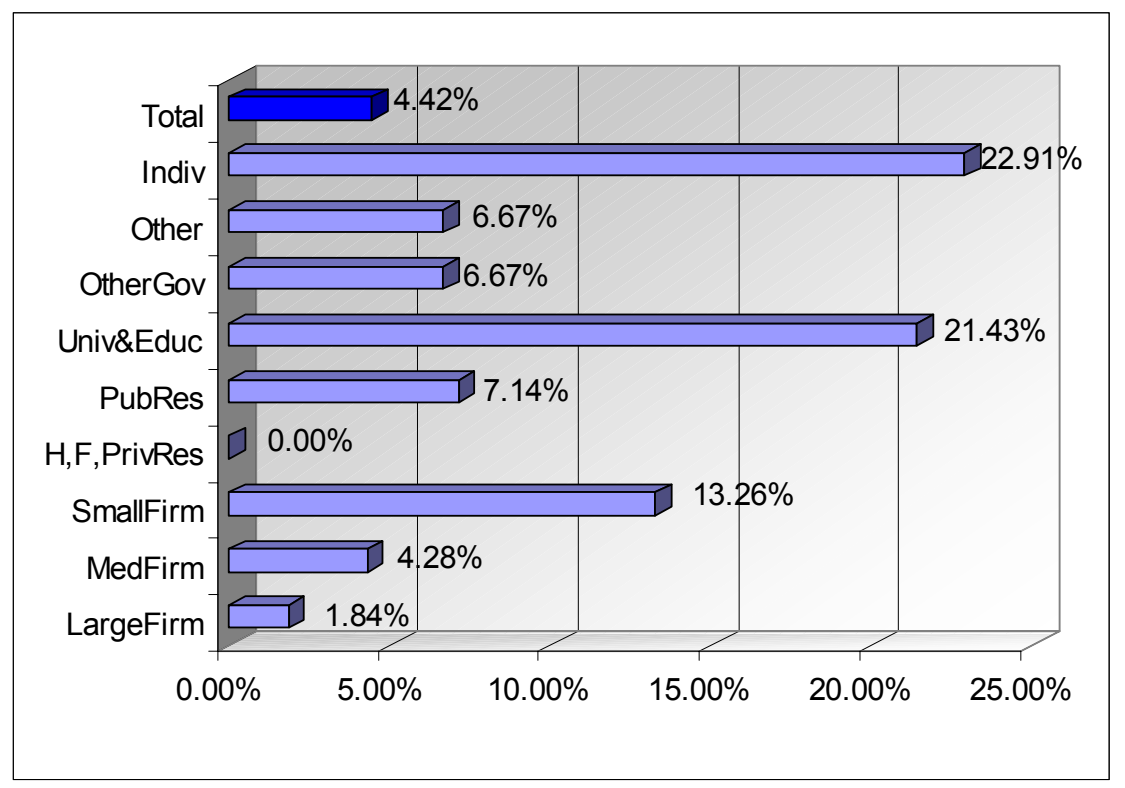

Source: European Commission (2005), Patval Survey.

Apart from motivations that induce PROs to adopt a patent licensing strategy, and conditions that motivated governments to approve the Bayh-Dole Act and subsequent patenting of university research results, what matters from a policy perspective are the possible implications that university patenting might have on innovative activity of companies placed downstream in the innovation process. University patenting represents a radical change in the traditional aptitude of openness and diffusion of scientific knowledge, whose consequences are not completely clear and explored.

While some authors (Etzkowitz et al., 2000) advocate an increased industrial finalisation of research activity promoted by PROs, and an increased role of PROs in local economic development, others (Florida, 1999; Salter et al., 2000) adopt an opposite perspective. According to this alternative point of view, public research institutions and universities should pay more attention to the training of human capital, and to the long-term development of a freely-available stock of knowledge that firms can then deploy for their innovation purposes. The attention posed by PROs on patenting is likely to determine a more than reasonable delay in the publication of results, and an alteration of the traditional system of incentives that normally characterize the behaviour of researchers. This change would determine a potential damage to the correct functioning of the scientific community, and ultimately result in a reduction of innovation potential for the whole economy, or in a modification of the research agenda of PROs towards more applied research and resolution of specific industrial needs (Dasgupta and David, 1994).

In sum, although the primary political motivation for allowing universities to patent their research results has been that of permitting them to assign exclusive licenses to private companies, and hence offer such companies adequate incentives to exploit results arising from university research, in the long run this policy might generate negative effects that would reduce (or counterbalance) the short-term advantages. Solutions to mitigate these negative effects, and reduce the trade-off between positive short-term advantages and negative long-term disadvantages are required. 


\subsection{The problem of "anti-commons" and fragmentation of IPRs}

If strong intellectual property rights favour the entry into the market for technology of small independent technology suppliers (and universities), and hence result in potential benefits to the economy, major problems arise when technologies are cumulative and systemic. Unfortunately, in several industries this is the case. Two canonical examples in this respect are those of the semiconductors and biopharmaceutical industries (see Hall and Ziedonis, 2001 and Hellen and Eisenberg, 1998).

A complex product based on a cumulative technology is made of several components and sub-systems, whose development and production is often demanded to different, independent firms. A system integrator willing to produce the complex product needs to collect all the different components from different producers. However, if property rights for each component have been assigned to the different producers, each producer has the right to exclude others from the use of her component, and hence to reduce the possibilities to the integrator to produce the complex product. The larger the fragmentation of property rights among independent organisations, and the larger the scope of each patent, the higher the effort and costs sustained by the system integrator to collect all the property rights needed to produce the complex product ${ }^{4}$. This problem gives rise to the so-called "tragedy of anticommons" (Hellen and Eisenberg, 1998).

If transaction costs were not a problem, the integrator would simply bargain with each patent holder the appropriate fee for the licensing of each component. However, in a more realistic world, the presence of transaction costs might induce the potential system integrator not to collect all the property rights. For instance, in order to extract the maximum value of her innovation, the holder of property rights over an important component of the complex product may use her patent to block ("hold-up") the collection of the entire set of property rights. If there are not useful technological alternatives, and if the scope of the patent is large enough to prevent the integrator to invent around, a "hold-up" problem is likely to occur.

Several causes bring to the emergence of a "hold-up" problem (Arora et al., 2001).

The first one is the extent of fragmentation of property rights amongst producers of components. When property rights are spread across dispersed patent holders, the incentive to collect all of them declines. Furthermore, the incentives to invest for the development of a complementary technology decline as well, given that each owner of a single component has to incur in higher transaction costs if she were to collect all the required property rights to produce the integrated product.

The second one is the capability to find alternatives of the technological components, or to develop the components in-house. If useful alternatives to the components can not be found, the bargaining position of the patent holder increases, hence increasing the overall level of transaction costs. Indeed, according to the traditional transaction costs literature (Williamson, 1975), such costs increase in the presence of specificity of investments and opportunistic behaviour of the agents. This is the case of holders of property rights over single components seeking to extract as much of the rent as possible.

Third, a "hold-up" problem is more likely to arise if holders of patents on key components are non-manufacturing firms (such as specialised technology suppliers or public research institutions). Such organisations lack downstream complementary assets needed to appropriate the returns from inventions, and are more likely to bargain more aggressively for

\footnotetext{
${ }^{4}$ See also Merges and Nelson (1990) and Scotchmer (1991) for a discussion on the impact of patent scope on first generation and second-generation innovators in cumulative and science-based innovations.
} 
obtaining licensing fees. By contrast, patent holders with market shares in the product market should find cooperative strategies more attractive, and should be less sensible to the amount of licensing fees.

Finally, the fourth cause of "hold-up" problems is the case of sequential innovations. Sequential innovations put the system integrator in a very challenging position. Once the integrator has collected the rights over a share of components, the bargaining power of the patent holders of the remaining components increases drastically. Indeed, the first purchases represent a sunk cost to the system integrator, which she aims at covering in any case, even at the cost of leaving at the remaining component holders the largest part of the surplus generated by the technology.

One of the main consequences of the "hold-up" problem is that firms, especially those with large investments in technology-specific assets, will patent more aggressively than otherwise expected (Ziedonis, 2004). The basic idea is related to the expectations of the system integrator to be suited for patent infringements. Given the dispersion of property rights, it is unlikely that a single firm can sign contracts (for the use of external technological components) with each patent holder, and it is much more likely that she will exclude those holders of technological components that are marginal or far from the core of the technology. However, this strategic choice increases the risks of infringement of property rights. Disputes for infringement of patents often end up with a settlement in which the two parts exchange their respective patent portfolio through cross-licensing agreements. The bargaining power of each part increases the larger the extent of the patent portfolio. As a consequence, firms increase ex-ante the size of their patent portfolios expecting to enter in future (cross-)licensing negotiations. In turn, a dynamic process arises: fragmentation of property rights in sectors based on cumulative and complex technologies increases the risks of infringement, given the difficulties in collecting all the property rights spread over several, dispersed agents; in order to mitigate the risks of infringement in subsequent licensing and cross-licensing transactions, firms patent more aggressively; as a consequence of this patenting behaviour, the fragmentation of property rights increases.

One of the sectors in which this mechanism is more visible is that of semiconductors and electronics. Empirical studies have demonstrated that, first, the extensive use of licensing and cross-licensing agreements is the direct consequence of large transaction costs that firms face when they try to put together dispersed property rights for the development of complex products (Grindley and Teece, 1997); second, firms that have made large investments in costly and rapidly depreciating facilities are more likely to patent more, in order to reduce the risks of being held-up by external patent owners, and to negotiate access to external technologies on more favourable terms (Hall and Ziedonis, 2001). For these companies, an increase in patenting is the result of a strategic concern, rather than simply reflecting an increase in $R \& D$ productivity.

Even though these results highlight potential social costs associated to a higher propensity to patent, and to assign stronger patent protection, the same authors (Hall and Ziedonis, 2001) suggest a positive effect deriving from the existence of strong IPRs to the sector dynamics, at least in the semiconductors industry. In this industry, stronger patent rights seem particularly critical to design firms, i.e. those smaller firms specialised in the design of new components or products not directly involved in manufacturing. Not only patents are important for defensive reasons and for improving their competitive position vis-à-vis market rivals. More relevant is the possibility to signal their capability to defend specific market niches, and hence attracting additional venture capital funds. 
Furthermore, recent empirical evidence suggests that the "anti-commons" problem may not be as ubiquitous as predicted by the literature. In the case of research tools in biomedical innovations, by analysing the results of interviews conducted with large pharmaceutical companies, small biotechnology firms, university personnel, and patent attorneys, Cohen et al. (2003) suggest that the problem of "anti-commons" is overall considered as manageable. Indeed, the vast majority of respondents declared that they have never encountered a breakdown problem, they have never modified a defined line of research due to impossibility to use specific discoveries or research tools (also because ample technological opportunities still exist in this field), and they consider that the difficulty of managing several licensing contracts and of paying relevant amount of royalties can be overcome. Moreover, the authors suggest possible working solutions to resolve the "anti-commons" problem and related restriction on access of research tools. Besides to licensing negotiations, firms might adopt a combination of different solutions, such as inventing around, offshore acquisition of alternative technologies, challenge in court, and eventually infringement. Apart from these private solutions, however, the problem needs an adequate institutional response made available to all potential users of upstream inputs. In the case of research tools, public databases provided by public consortium might be one of such solutions.

Apart from these private solutions, however, the problem needs an adequate institutional response made available to all potential users of upstream inputs. In the case of research tools, public databases provided by public consortium might be one of such solutions. In fields different from biomedical research tools other "public" solutions might be available or likely. For instance, in the case of software, the provision of open source software usually goes along with a Generalised Public Licence (GPL), according to which the producer of a open source program requires that all modifications of the program be subject to the same rules of openness, i.e. the source code of all modifications ought to be made available to the public as the original program (Lerner and Tirole, 2002b). It has been demonstrated that this solution creates a co-ordination condition between the different program producers and users, and favours the formation of a public equilibrium (Gambardella and Hall, 2005).

\subsection{The social cost of litigation}

Another negative effect associated with a system of strong intellectual property protection is that the enforcement of the property rights is usually very costly, and, in general, the social loss of resources due to litigations in legal disputes is relevant. Furthermore, these costs are unevenly sustained by the different actors (individuals vs. firms, large firms vs. small firms, firms with different characteristics). In turn, litigation costs may both mitigate the positive effects arising from strong IPRs, and reduce the incentives to innovate in the long run, especially in those technological fields where IPR protection is mostly relevant.

Statistics on litigations show that the crude number of patent suits filed in the US has constantly grown during the last two decades - although with some differences among different technological areas - following the constant increase of patenting over the same period of time. If the growth of patenting is taken into account (i.e., if percentages of suits filings per thousand of patents are considered instead of crude number of filings), no trend increase in the filing of suits can be observed. For instance, in a recent study, Lanjouw and Schankerman (2003) analyse the filing rates by different technology fields (drugs, other health, chemicals, electronics, mechanical, computers, biotechnology, and miscellaneous) during three time periods: $1978-84,1985-90$ and 1991-95. They show that the propensity to litigation varies among fields. For all the technological fields, and for the whole period 19781995, the average number of suits filed (per thousand patents) is 19. The lowest rates are for 
chemicals (11.8 suits filed per thousand patents), electronics (15.4) and mechanical (16.9). The highest rates of filings are in "other health", miscellaneous, computers and biotechnology. Interestingly, computers and biotechnology are newer technological areas compared to the others, hence demonstrating that litigation is mostly expected in those technological fields characterised by greater uncertainty about legal outcomes. However, when time trends are considered, and once the growth in patenting is taken into account, the study shows that no increase in litigation (in relative terms) occurred in any technological field. Furthermore, very few patent suits actually go to trial. Approximately $95 \%$ of all patent suits settle either before or during trial. In particular, $78 \%$ settle before the pre-trial hearing, an additional 16\% settle before trial, and 1\% settle during trial.

Even though most patent suits end up with a settlement before or during trial, about half of the estimated legal costs of litigation are incurred before the end of the discovery phase (AIPLA, 2001), thus making litigation extremely costly. Moreover, from a social perspective, settlements before trials are likely to lead to collusive outcomes, hence generating a social loss of resources.

Estimates of direct costs due to litigation are difficult to provide, and generally result in divergent figures. Relatively to the amount of risk, patent litigation costs may spread from half a million dollar to three million dollars (AIPLA, 2001). Relatively to the number of claims that are under examination, direct costs are estimated in half a million dollars per claim (Barton, 2000). In aggregate terms, annual patent suits may generate more than 4 billion dollars in legal fees (Berman, 2002).

Furthermore, the time spent in trials is generally very long. The time lag between a suit filing and the final resolution has been estimated in 32 months on average, in the case of District Court suits (Magrab, 1993). Similarly, another evidence on the length of suits shows that while patent suits only represent 0.57 percent of all civil cases in the federal courts, they account for over nine percent of those that require a trial of twenty days or more (Berman, 2002).

The reason that makes legal costs so relevant is twofold. On the one hand, legal standards associated to patents and patent suits make the environment in the federal courts unfriendly. According to Hall et al. (2004), one of the difficulties opponents in patent disputes find concerns the process of proofs formation. In order to prove a claim invalid "clear and convincing" evidence has to be provided, while in ordinary civil suits the simple "preponderance" of proofs is required. This difference in standards makes patent suits particularly costly, and creates strong evidentiary barriers that challengers have to face. As a matter of facts, since the creation of CAFC, and subsequently to the rapid increase in patenting during the last decades in the US, the rate of success of challenges to patent validity has declined from fifty to about thirty percent (Lemley and Allison, 1998).

On the other hand, the ways in which attorneys face patent suits contribute to the increase in direct legal costs (Berman, 2002). First, if compared to the overall monetary value that challengers can gain from the suit, the amount of legal fees associated to each patent suit can be considered of marginal relevance. Firms often tend to neglect the importance of such costs, convinced that additional legal costs might generate (more than) proportional litigation advantages. They tend to prefer high-quality lawyers adopting an aggressive and costly approach. Furthermore, attorneys usually prefer firms aiming at avoiding early settlements instead of waiting for trial response. The main reason is not that lawyers consciously avoid early settlements, but tend to prefer more aggressive firms expecting to earn more money from protracted patent litigations. In turn, those firms adopting a less aggressive approach are eventually selected out of the financially competitive market of attorneys. As a matter of 
facts, according to the study of Berman (2002), the median legal fees for a case of patent litigation through court trial is about two million dollars per side, and it is constantly increasing.

Apart from direct costs, patent litigations generate indirect costs whose relevance is even more important for the society on the whole. Often, rather than the actual amount of legal costs associated to litigations, it is the risk of incurring in such costs to create negative effects and to induce firms to modify their behaviours accordingly. In industries where patent protection is stronger, the risk of being suited for patent infringement and hence incurring the direct legal costs associated to a trial creates a barrier to entry, and prevents firms from investing in innovations. In turn, contrarily to policy expectations, a system of strong property rights might reduce the overall level of investments in R\&D and innovative activities, especially for small firms that are most exposed to the risks of patent litigations. Since small firms often lack the required financial resources to sustain long and costly litigation causes, they under-invest in those areas where patent protection of large firms is higher.

This conclusion is supported by earlier empirical evidence. For example, Lerner (1995) shows that small firms reduce R\&D investments in the fields in which the threat of litigation from larger firms is high. Similarly, Lanjouw and Lerner (2001) find that large firms use the instrument of preliminary injunction to discourage $R \& D$ by small firms. Preliminary injunction may result in the court decision to prevent both parts involved in a patent litigation to use the patent under dispute, sometimes by imposing a stop in the production of goods that incorporate the innovation protected by that patent. If a large firm can manage a similar risk, the lack of adequate financial resources can represent an unaffordable obstacle for smaller firms, especially if their activity is concentrated on a single business. In their study based on 252 trials filed in Europe between January 1990 and June 1991, Lanjouw and Lerner (2001) show how the use of preliminary injunctions is a specific prerogative of large firms, which use this instrument twice compared to smaller firms. Large firms use preliminary injunctions as a means to prevent other firms to invest in the same technological areas in which they have been granted for patents. Even in the cases in which patent violation is not strongly demonstrable in court trials, small firms may lack the financial resources to file a patent suit. This behaviour allows larger firms to maintain a monopolistic control over specific technological areas, and eventually results in higher prices for the products that integrate the technology protected with patents. Apart from possible distortion in prices, however, from the social point of view the most negative effect is that the enforcement process of intellectual property rights undermines the R\&D incentives of small firms (Lanjouw and Schankerman, 2003). Moreover, the risk of litigation for small firms is larger and patent suits can be longer with respect to firms with large patent portfolios, because the latter may avoid suits or long settlements through the development of cooperative agreements after repeated interactions or disputes with other firms (Lanjouw and Schankerman, 2004).

Furthermore, in the case of cumulative inventions, excessive protection stated by previous sentences of courts in favour of patent holders in cases of patent infringement may induce subsequent innovators to reduce their investments in that research trajectory (Llobet, 2003). The reason is that, in order to exploit an innovation based on a cumulative technology, the patent holder needs to license that patent to other firms that will build on it and develop subsequent innovations. A strong patent protection, stated by positive previous court sentences or settlements, will provide the patent holder with higher licensing fees - i.e., her bargaining power rises, as well as her capacity to extract higher rents from licensing. At the same time, however, a lower number of firms will be willing to invest in that research trajectory and hence to enter into licensing agreements with the original patent holder. The two effects go in opposite directions. However, the stronger the protection given to patents in 
cumulative technological domains, the higher the likelihood that the second effect dominates the first one. The result of previous patent litigations might create barriers to entry, and might discourage more small improvements that would benefit the patent holder, in particular, and the whole society, in general terms.

Apart from direct and indirect costs associated to patent litigation, the enforcement of patent rights has a strong effect on industry dynamics as well, and especially on the role played by smaller firms. The effects of strong property rights and high costs associated to patent litigation are particularly severe for smaller firms. This fact counterbalances the positive effect arising from strong IPRs on such a category of firms. While strong IPRs favour the entry in the market of small firms specialised in the supply of technologies or technological components, the enforcement of strong IPRs mainly punishes the same set of firms. High costs of enforcement lower their incentives to innovate, and prevent (small) firms from entering those technological areas strongly protected by incumbent patent holders.

This aptitude is confirmed by empirical evidence. In one of the earliest studies on this issue based on a survey of 376 firms, Koen (1991) shows that, even though many smaller firms were aware of the fact that their patents were violated, in $55 \%$ of cases they were not taking any action to enforce their property rights, because of the high costs (and long time delays) associated with patent enforcement. Similarly, Cohen et al. (2000) show that the stronger motivations identified by small firms for avoiding to protect their innovations with patents are the costs associated with patent application and enforcement. In sum, although strong intellectual property rights are needed to technology-based small firms to enter the market and to supply technologies to downstream users, the costs associated to the patent system and to the enforcement of patent rights mitigates this positive effect and might result in a reduced than expected entry of smaller firms. Differences in costs associated to patents in different countries - e.g. the US vs. Europe - might induce different behaviours in firms operating in different markets.

\section{Software technology: open science and patent system}

The software technology represents a peculiar case for understanding the advantages and drawbacks of differential levels of intellectual property protection. In fact in recent years software technologies have been characterised both by a strengthening of the patent system and a trend towards the sharing and free revealing of the software source code. The traditional mean of protecting intellectual property is instead the copyright institution, associated to proprietary licenses that usually limit the use, and deny the possibility to copy, modify and distribute the software. Furthermore, proprietary software is usually protected by trade secret and therefore the source code is not disclosed.

Several scholars are trying to understand the sustainability of different models of IP protection, the reasons for different behaviour of actors, and the implications on the market dynamics.

The empirical and historical analysis of software patenting documents a progressive strengthening of the patent system occurred first and foremost in the US and subsequently in Europe. Software was not patentable, given that patent offices have not allowed until recently the patenting of mathematical formulae and mental processes. The US Supreme Court in 
Gottschalk vs. Benson ${ }^{5}$ in 1972 did not consent to patent mathematical algorithms. During the 1970s, courts decision followed this line, not allowing patents of "pure" software, and in particular of inventions whose novelty lied exclusively in a computer program. The courts position changed in 1981, when in Diamond vs. Diehr ${ }^{6}$ it was held valid a patent for a process of temperature measurement of a machine by using a computer and a known equation. However, the protection did not cover other different applications. Software patenting was further strengthened in 1994 with In re Appalat ${ }^{7}$, when it was granted a patent for an algorithm applicable to a general purpose computer, without the need of specifying the applications of the computer program. Finally, in 1998 with State Street Bank \& Trust vs. Signature Financial Group ${ }^{8}$, the court allowed business methods patents (Cohen and Lemley, 2001). In Europe the recent EU Directive on computer-implemented inventions, on which a lively debate is still in progress, is moving towards the patentability of software.

The growth of software patents is however precedent to the policy changes just recalled. Recent studies have identified the existence of software patents through search procedures of words and combination of words referring to software (like software, computer program, algorithms, etc.) in the title and abstract of patents. Bessen and Hunt (2004) have illustrated a continuous growth in the number of software patents at the USPTO in the last 25 years. The number of patents is jumped from 1,080 in 1980s to more than 24,000 in 2002 (Figure 3). The website of the FFII software patents groups shows that at the EPO the number of patents is smaller but rapidly growing especially since $2000^{9}$.

Figure 3 - Software patents in US and Europe

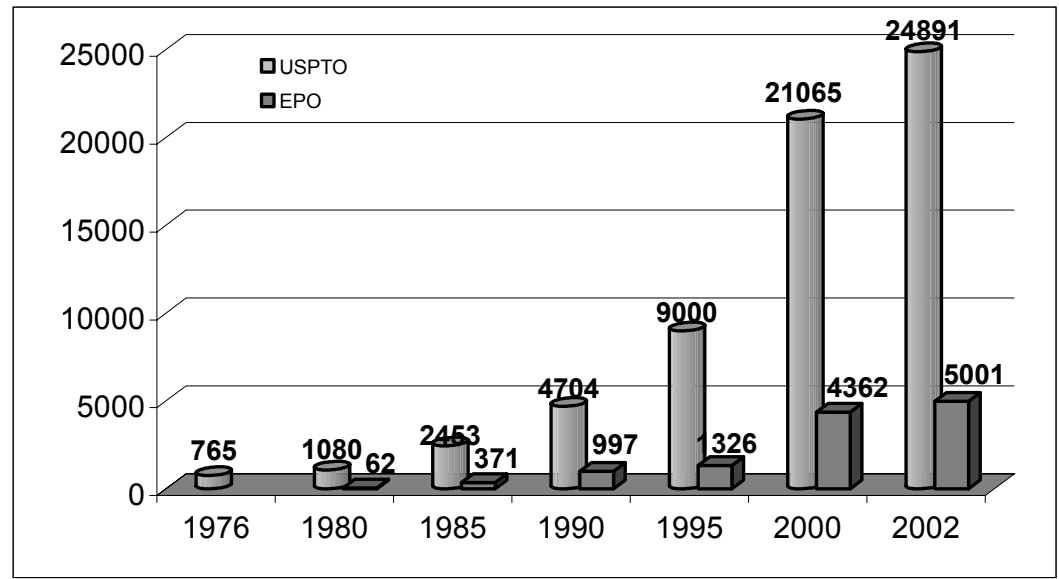

Source: Bessen and Hunt (2004) and http://swpat.ffii.org/patents/stats/country stat.en.html.

Bessen and Hunt (2004) also highlight the characteristics of patents and assignees of US software patents compared to all other patents in 1990-1995 (Table 3). It is worth noting that assignees are mostly companies, that the share of patents from individuals is lower for software than for other patents, that software patents are on average most cited and have a

\footnotetext{
5409 U.S. 63 (1972).

${ }^{6} 450$ U.S. 175 (1981).

733 F.3d 1526 (Fed. Cir. 1994).

${ }^{8} 149$ F.3d 1368 (Fed. Cir. 1998), cert. Denied, 525 U.S. 1093 (1999).

${ }^{9} \mathrm{http}: / /$ swpat.ffii.org/patents/stats/country stat.en.html. Note that the numbers in the two patent systems are not perfectly comparable since they adopted different search procedures. However they provide a clear picture of the size and dynamics of the phenomenon in the two patent systems.
} 
larger number of claims than other patents. This suggests that software patents have a potential broader application with respect to the rest of patents, which have less citations and claims. Moreover, the median of sales is larger for software patents assignees, suggesting a larger company size. Finally, the share of US assignees and inventors is larger for software patents. Contrarily, The statistics on EPO patents report that $46.84 \%$ of patents in the overall period have a US applicant, $21.76 \%$ a Japanese applicant. Among the European countries, Germany and Great Britain have the largest share of software patents (respectively $4.90 \%$ and $4.76 \%)$.

Table 3 - Characteristics of software patents in the US, 1990-1995

\begin{tabular}{|lrr|}
\hline & Software & Other patents \\
\hline Characteristics of the Assignee & & \\
Companies & $88 \%$ & $80 \%$ \\
Individuals/Not assigned & $11 \%$ & $18 \%$ \\
Government & $2 \%$ & $2 \%$ \\
U.S. assignee & $70 \%$ & $51 \%$ \\
U.S. inventor & $69 \%$ & $53 \%$ \\
Median of company sales (million \$) & 13,382 & 8,940 \\
\hline Characteristics of the Patent & & \\
Average number of forward citations & 9.7 & 4.6 \\
Average number of claims & 16.8 & 12.6 \\
\hline
\end{tabular}

Source: Bessen and Hunt (2004)

The fact that large companies are the larger software patent holders seems to suggest that the increasing patentability of software may create high barriers for SMEs in the software sector. This hypothesis is also confirmed by the sectoral distribution of US software patents reported by Bessen and Hunt (2004). Seventy-five percent of software patents are applied by firms in manufacturing sectors (28\% in Electronics, 24\% in Mechanical, 9\% in Instruments) while $25 \%$ by firms in non-manufacturing sectors, and only $7 \%$ in the software sector. It is also worth emphasizing that software patenting by firms in other sectors may create barriers for small and new firms in the software sector and to the emergence of a specialized market for software technologies.

Bessen and Hunt (2004) finally put forward that software patents might not provide additional incentives to innovation in this sector. In fact they show that R\&D investments were already high before the IP strengthening, and that the annual rate of growth of R\&D investments is dropped from an average of $16 \%$ in the 1980 s to $11 \%$ in the 1990 s. They point out that firms have essentially substituted $R \& D$ investments with increasing patenting. From a policy perspective this also implies that patent protection is not essential for the development of the software industry. Furthermore, the hypothesis of stronger incentives to innovation is scarcely supported from the recent growth of the number of developers of free/open source software. A rising number of innovators/developers prefer in fact sharing instead of protecting software knowledge (David, 2003; Lerner and Tirole, 2002a).

David (2003) casts doubt on the fact that traditional means for protecting innovations are necessary for new technologies, discussing the fact that new technologies may require different institutional mechanisms and, in particular, mechanisms closer to the open science organization. 
On the one hand a balance between IP protection of inventions and open science is considered healthy for technological progress and diffusion and for the creation of new firms. However the trade-off is that strong IP limits the possibility and speed of diffusion and further developments, but may positively act as a relevant signal for new and small firms.

The adoption of mechanisms of open science communities like reputation, priority and cooperation favours the development of scientific inventions. Openness allows an open validation of research methods and results, and may avoid duplication of efforts (see Dasgupta and David, 1994 for specific cases in which inefficient duplications may occur in open science). On the contrary intellectual property protection on research limits the possibility of knowledge access from new and young scientists, and in particular limits the circulation of information and research tools. Moreover, it may delay the publication of scientific research outcomes ${ }^{10}$ and lead to some of the anti-commons problems that may occur in the supply of upstream inputs and research tools.

In the open source software (OSS) system, developers may freely contribute to the development of a software project, whose source code can be freely downloaded and modified according to the licensing scheme attached to the project (for a description and discussion of the OSS licenses see Lerner and Tirole, 2002b, Giuri et al. 2002). The source code is distributed together with the object, binary software, under license schemes that allow anyone to download the source code, make modifications and redistribute the software either for free or for a relatively small fee (Raymond, 1999).

The meaning of free software is associated to the Free Software Foundation, founded by Richard Stallman in 1983, and the GNU General Public License (GNU/GPL) that establishes very strong users' rights (Stallman, 1999) ${ }^{11}$. Later on, the diffusion of open source software increased substantially after the introduction of Linux by Linus Torvalds in 1991, and the creation of the Open Source Initiative (OSI). The OSI initiative launched an Open Source Definition and an OSI Certification Mark applicable to OSS licenses. The OSI also introduced additional types of licenses, which facilitate the commercial distribution of open source software with respect to the GNU/GPL.

The empirical evidence on the diffusion of open source software is suggesting that the open source model may produce an intensified among large software producers like in the cases of Linux vs. Windows, or Apache vs. Microsoft ${ }^{12}$. Apart from large OSS projects like Linux or Apache, many smaller projects have been introduced in the last few years. For example SourceForge.net, the largest web repository of OSS projects created in 1999 hosts at the beginning of 200597,950 registered projects and 1,041,049 users ${ }^{13}$. However, most of them are composed by a very small number of participants and are characterised by a skewed distribution of activity levels (Giuri et al., 2004).

What makes the study of open source software particularly relevant in the debate of strong vs. weak IP protection, is that on the one hand the open source system of knowledge production share some of the mechanisms of the open science communities, where individuals signal their qualities by contributing to a common project, by disclosing their innovation, and by

\footnotetext{
${ }^{10}$ In Europe the priority of a patented invention starts from the filing date of the patent. For this reason, US inventors delay the publication of scientific outputs if they intend to patent in Europe.

${ }^{11}$ GPL allows users to have access to the source code on condition that he/she will make the source code freely available (or at the distribution costs which tend to be zero with the Internet) to third parties (copyleft property).

${ }^{12}$ Empirical evidence on the web server software is available at http://www.netcraft.com/survey/archive.html. For some models mainly inspired by the competition between Linux and Windows see Dalle and Julien (2001), Saint Paul (2001) and Casadeus and Ghemawat (2003).

${ }^{13} \mathrm{http}: / /$ sourceforge.net/ - last visited: March $26^{\text {th }}, 2005$
} 
refereeing the others' contribution on a peer review basis. On the other hand some OSS producers aim at making profits in the business environment, without protecting their intellectual capital through patents or trade secret.

Von Hippel and von Krogh (2003) discuss the open source system as an intermediate model situated between the strong intellectual property protection system (called "private") and the "collective action" model.

The latter shares some characteristics of the open science communities and of industrial contexts in which an informal exchange of know-how among producers is often frequent (Allen, 1983; von Hippel, 1987). The cases documented by Allen (1983) and von Hippel (1987) deal with information that are difficult to be protected through patents, and free revealing is more rewarding than maintaining the secret. In the case of the iron industry in the $19^{\text {th }}$ century (Allen, 1983) manufacturers share information which is critical for improving furnaces performances and productivity. In the case of steel minimill process discussed by von Hippel (1987) the information shared among manufacturers is mainly non critical and incremental, and the benefit prevails over the cost of sharing the information.

The idea discussed by von Hippel and von Krogh (2003) is in fact that a collective action model can emerge as a response to a market failure in the exchange and protection of knowledge. In this case maintaining the secret is not an available option for the manufacturers, since the effectiveness of protection is very scarce. They can therefore either contribute to the common stock of available knowledge or free ride. For the functioning of a collective action model the private reward from contributing should be larger than the private reward from free riding. However the risk of free riding, that is of waiting for others' contributions and use them, should be corrected through the provision of right incentives like monetary subsidies or like the rule of priority typical of the open science model (Dasgupta and David, 1994).

Von Hippel and von Krogh define the open source model as "private-collective" and one of its main characteristics is that the typical innovators are the users instead of the software producers. For producers the private incentives to innovate and protect are greater since they expect to have a larger target market for the innovation, which is composed by many users. By contrast the expected benefits from the innovation for users derive from the internal use, unless licensing the innovation to other users is an available option. For users therefore the loss of profits from revealing is lower than the benefits of internalising knowledge from a common pool. The open source system is in fact typical of settings in which users innovation are relevant for the producers, and therefore the sharing of information among users and producers is also beneficial for the latter (von Hippel, 1988; Harhoff et al., 2003). The other actors for which the open source software system is viable are the manufacturers of complementary goods or services. The cost of revealing the information (through posting messages on the web) and reducing profits by sharing non core information for the producer is lower than the reward from network effects and from the sales of complementary goods and services. Moreover in the OSS "private collective" model, contrarily to the collective action model, individual benefits from free revealing like learning and enjoyment from programming and contributing to a common project are available only to participants who reveal the information and not to free riders (von Hippel and von Krogh, 2003).

Gambardella and Hall (2005) emphasise the fact that open source software or the production of scientific inputs may often require downstream complementary investments for appropriating the returns from innovations. The problem is that if inputs in the production process are freely available, than the downstream market can be highly competitive since entry would not be precluded. Therefore the returns from investments would be very low and 
not sufficient to cover the complementary investments in downstream assets. On the contrary IP protection of upstream inputs may raise the cost of entry, limit competition and allow downstream actors to obtain rents from their investments. One possible solution could be narrowing the protection only to the innovations of the downstream producers, thus reducing the potential broad blockage of entry of downstream firms if protection is allowed for general knowledge. Therefore, the development of open source software can facilitate entry and competition from small firms only when their competitive advantage resides in the complementary assets for the innovation, although with free inputs larger firms may enjoy advantages from larger scale investments in downstream activities.

Finally, for some software technologies, the sharing of software knowledge may facilitate diffusion and the emergence of a standard. For this reasons the protection of software technologies characterised by network externalities may favour the creation of monopolies (Bessen and Hunt, 2004).

\section{Conclusions}

The aim of this paper was to analyse the characteristics of two alternative systems of IP protection - namely, strong IPRs and open science/open source - and the effects of both on market dynamics, and more precisely on small and large firms, and on entry of technologybased firms into the market. From the analysis carried out so far it is possible to draw some conclusions. First, inter-sectoral differences are relevant and have to be taken into consideration. While the two models might operate together in some specific sectors (such as software), in others only one of the two seems mostly appropriate. Conditions such as the characteristics of the knowledge base, the presence of economies of scale in research activities, the complexity and the cumulativeness of the technology to be developed are key in defining which model offers the strongest incentives to innovators.

Second, also related to the first issue, complementary assets become crucial. If new technological knowledge requires large investments in complementary assets in order to be fully exploited, the willingness to invest in such assets will be linked to the possibility to use the relevant knowledge on a private base. However, an open source model might also be appropriate in the case in which business actors mainly compete on the basis of complementary assets. Related to this point, understanding the different behaviour of large and small firms in the markets for technology and in the investments in complementary assets

becomes crucial. For small firms focused on the development and commercialisation of technologies rather than products the IPR system seems necessary. In sectors like the pharmaceutical and biotechnology this is the case. On the other hand, the open source model might favour the entry in the software industry of new and small firms that can freely access the technological knowledge and focus on downstream activities.

Third, even though clear evidence has not been provided, and the literature is not univocally oriented toward this question, the two models can be expected to generate different incentives in the development of radical vs. incremental innovations. Usually, radical innovations require larger investments and are more risky. Inventors will sustain such costs and risks only if they can expect to exploit the innovation on a large market, preferably on a monopolistic base. If this is the case, only under the strong IPR model radical innovations can be pursued. By contrast, if an open source model operates, the possibility to promote further developments on a new scientific and technological knowledge is spread over several agents, all using the same (public) new knowledge. Hence, in an open source model, not only a rapid 
diffusion of the innovation should be expected, but also a rapid process of introduction of incremental modifications to the same innovation.

\section{References}

AIPLA (American Intellectual Property Law Association) (2001), Report of Economic Survey, Washington, D.C.

Allen R.C. (1983), "Collective Invention”, Journal of Economic Behavior and Organization (4), 1-24.

Arduini R., Cesaroni, F. (2004), "Development and Diffusion of Environmental Technologies", in Cesaroni, F., Gambardella, A., and Garcia-Fontes, W. (eds.), R\&D, Innovation and Competitiveness in the European Chemical Industry, Kluwer Academic Publishers, Dordrecht.

Arora A. (1995), "Licensing Tacit Knowledge: Intellectual Property Rights and the Market for KnowHow", Economics of Innovation and New Technology 4, 41-59.

Arora A. (1997), "Patent, Licensing and Market Structure in the Chemical Industry", Research Policy 26, 391-403.

Arora A., Fosfuri A. (2003), Licensing the Markets for Technology, Journal of Economic Behaviour and Organization, 52, 277-295.

Arora A., Fosfuri A., Gambardella A. (2001), Markets for Technology: The Economics of Innovation and Corporate Strategy, The MIT Press, Cambridge MA.

Arora A., Gambardella A. (1998), "Evolution of Industry Structure in the Chemical Industry", in Arora, A., Landau, R., and Rosenberg, N. (eds.) Chemicals and Long-Term Economic Growth, John Wiley \& Sons, New York.

Arora A., Merges R.P. (2004), "Specialized Supply Firms, Property Rights and Firm Boundaries", Industrial and Corporate Change, 13(3): 451-475.

AUTM (1999 and 2001) AUTM Licensing Survey (FY 1999 and 2001).

Barton, J. H. (2000), "Reforming the Patent System." Science 287: 1933-1934.

Berman B. (eds.) (2002), From Ideas To Assets. Investing Wisely In Intellectual Property, John Wiley \& Sons, New York.

Bessen J., Hunt R.H. (2004), An empirical look at software patents, WP No. 03/17R, Federal Reserve Bank of Philadelphia., available at www.researchoninnovation.org

Carlsson B., Frihd A.C. (2000), “Technology Transfer in United States Universities”, paper presented at The Eighth International J.A. Schumpeter Society Conference - The Millennium Conference Change, Development and Transformation: Transdisciplinary Perspectives on the Innovation Process, Manchester (UK), June $28^{\text {th }}-$ July $1^{\text {st }}$.

Casadesus-Masanell R., Ghemawat P. (2003), "Dynamic Mixed Duopoly: A Model Motivated by Linux vs. Windows," Strategy Unit Working Paper 04-012, Graduate School of Business Administration, Harvard University.

Cesaroni F. (2003), "Technology Strategies in the Knowledge Economy: The Licensing Activity of Himont", International Journal of Innovation Management, vol. 7 (2), June.

Cesaroni F., Mariani M. (2001), "The Market for Knowledge in the Chemical Sector", in Guilhon B. (eds.), Technology and Markets for Knowledge, Kluwer Academic Publisher, Boston.

Cohen J.E., Lemley M.A. (2001), Patent Scope and Innovation in the Software Industry Columbia Law Review, 89, 1, 1-57. 
Cohen W.M., Arora A., Walsh J.P. (2003), "Effects of research tool patenting and licensing on biomedical innovation", in Merrill S.A. and Cohen W.M. (eds.), Patents in the KnowledgeBased Economy, National Academic Press, Washington, DC.

Cohen W.M., Nelson R.R., Walsh J.P. (2000), "Protecting Their Intellectual Assets: Appropriability Conditions and Why U.S. Manufacturing Firms Patent (or Not)", NBER Working Paper \#7552, February.

Dalle J., Jullien N.. (2001), Open-source vs. Proprietary Software. Working paper. http://opensource.mit.edu/online_papers.php.

Dasgupta P., David P.A. (1994), Towards a new economics of science, Research Policy, Vol. 23, pp. 487-521.

David P.A. (2003), Does the New Economy Need All the Old IPR Institutions? Digital Information Goods and Access to Knowledge for Economic Development. Presentation to the UN University WIDER Conference New Economy in Development, Helsinki, 10-11 May 2003.

Etzkowitz H., Webster A., Gebhardt C., Cantisano Terra B.R. (2000), "The Future of the University of the Future: Evolution of Ivory Tower to Entrepreneurial Paradigm", Research Policy, 29, p. 313-330.

European Commission (2005), The value of patents for today's economy and society, Report (forthcoming).

Florida R. (1999), "The Role of the University: Leveraging Talent, not Technology", Issues on Science and Technology, XV(4), p. 67-73.

Forbes (1985), “A change in the legal climate", October 7, p. 41.

Forbes (1986), “A weapon at last”, March 10, p. 46.

Fortune (1986), "The surprising new power of patents", June 23, p.57.

Franke N., von Hippel E. (2003), "Satisfying Heterogeneous User Needs via Innovation Tool Kits: The Case of Apache Security Software," Research Policy, 32, 1199-1215.

Freeman, C. (1968), "Chemical Process Plant: Innovation and the World Market", National Institute Economic Review 74, 931-941.

Gallini N.T. (1992), "Patent policy and costly imitation", Rand Journal of Economics 23(1).

Gallini N.T. (2002), “The Economics of Patents: Lessons from Recent U.S. Patent Reform, Journal of Economic Perspectives, 16, 131-154.

Gambardella A., Hall B. (2005), "Proprietary vs Public Domain Licensing in Software and Research Products", Research Policy, (forthcoming).

Giuri P., G. Rocchetti, S. Torrisi (2002), Open source software: from open science to new marketing models. An enquiry into the economics and management of open source software. LEM Working Paper No. 2002/23, Sant'Anna School of Advanced Studies, Pisa.

Giuri P., Ploner M., Rullani F., Torrisi S. (2004), Skills and Openness of OSS Projects: implications for performance, LEM Working Paper No. 2004/19, Sant'Anna School of Advanced Studies, Pisa.

Graham S., Mowery D.C. (2003), "Intellectual Property Protection in the U.S. Software Industry", in Cohen W., Merrill S. (eds) The Patent System in the Knowledge-Based Economy. Washington, DC: National Academies Press.

Granstrand O. (2005), "Innovation and Intellectual Property Rights", in Fagerberg J., Mowery D.C., Nelson R.R. (eds.) “The Oxford Handbook of Innovation”, Oxford University Press. 
Grindley P.C., Nickerson J. (1996), 'Licensing and Business Strategy in the Chemical Industry', in Parr, R. and Sullivan, P. (eds.), Technology Licensing: Corporate Strategies for Maximizing Value, John Wiley and Sons, New York.

Grindley P.C., Teece D.J. (1997), "Licensing and Cross-Licensing in Semiconductors and Electronics", California Management Review 39(2), 8-41.

Hall B.H, Ziedonis R.H. (2001), "The patent paradox revisited: an empirical study of patenting in the U.S. semiconductor industry, 1979-1995", RAND Journal of Economics 32(1), Spring, 101128.

Hall B.H. (2003), "Business Method Patents, Innovation, and Policy" Economics Department, University of California, Berkeley, Working Paper E03-331.

Hall B.H. (2004), Exploring the patent explosion, NBER Working Paper No. 10605.

Hall B.H., Graham S., Harhoff D., Mowery D.C. (2004), "Prospects for Improving U.S. Patent Quality via Postgrant Opposition", in A.B. Jaffe, J. Lerner and S. Stern (eds.), Innovation Policy and the Economy, volume 4, MIT Press, Cambridge, MA.

Harhoff, D., Henkel, J., Von Hippel, E. (2003), "Profiting from Voluntary Information Spillover", Research Policy 32, 1753-1769.

Heller M., Eisenberg R. (1998), "Can Patents Deter Innovation? The Anticommons in Biomedical Research”, Science 28, May 1st, 698-701.

Jaffe A.B. (2000) "The US Patent System in Transition: Policy Innovation and the Innovation Process", Research Policy 29, 532-557.

Kortum S., Lerner J. (1999) What is Behind the Recent Surge in Patenting, Research Policy 28, 1-22.

Lakhani K., von Hippel E. (2003), "How Open Source Software Works: 'Free' User-to-User Assistance," Research Policy, 32, 923-943.

Lamoreaux N., Sokoloff K. (1997), "Location and Technological Change in the American Glass Industry during the Late Nineteenth and Early Twentieth Centuries", NBER Working Paper 5938, NBER, Cambridge MA.

Lamoreaux N., Sokoloff K. (1999), "Inventors, Firms, and the Market for Technology: US Manufacturing in the Late Nineteenth and Early Twentieth Centuries", in Lamoreaux, N., Raff, D., and Temin, P. (eds.), Learning by Firms, Organizations, and Nations, University of Chicago Press, Chicago.

Lanjouw J.O., Lerner J. (2001), “Tilting the Table? The Predatory Use of Preliminary Injunctions," The Journal of Law and Economics, 44(2), 573-603.

Lanjouw J.O., Schankerman M., (2003), "An Empirical Analysis of the Enforcement of Patent Rights in the United States," in Cohen W. and Merrill S. "Patents in the Knowledge-Based Economy", National Academy Press: Washington, D.C.

Lanjouw J.O., Schankerman M., (2004), "Protecting Intellectual Property Rights: Are Small Firms Handicapped?" Journal of Law and Economics, 45-74.

Lemley M.A., Allison J.R. (1998), "Empirical Evidence on the Validity of Litigated Patents," American Intellectual Property Law Association Quarterly Journal 185: 26.

Lerner J. (1995), Patenting in the Shadow of Competitors, Journal of Law and Economics, vol. 38, 463-96.

Lerner J. (2002), Patent protection and innovation over 150 years, NBER Working Paper 8977.

Lerner J., Tirole J. (2002a), "Some Simple Economics of Open Source", Journal of Industrial Economics (2), 197-234. 
Lerner J., Tirole J. (2002b), “The Scope of Open Source Licensing”, NBER Working Paper No. 9363 (2002).

Lerner J., Tirole J. (2004), “The Economics of Technology Sharing: Open source and beyond”, NBER Working Paper No. 10956.

Llobet G. (2003), "Patent litigation when innovation is cumulative". International Journal of Industrial Organization 21, 1135-1157.

Magrab E.B (1993), "Patent Validity Determinations of the ITC: Should U.S. District Grant Them Preclusive Effect?” Journal of the Patent \& Trademark Office Society 75(125): 127-35.

Mazzoleni R., Nelson, R. (1998) "The benefits and costs of strong patent protection: a contribution to the current debate", Research Policy 27, 273-284.

Merges R., Nelson R. (1990) On the Complex Economics of Patent Scope, Columbia Law Review 90 (4), 839-916.

Mowery D.C., Nelson R.R., Sampat B.N. and Ziedonis A.A. (2001). "The growth of patenting and licensing by U.S. universities: an assessment of the effects of the Bayh-Dole act of 1980", Research Policy 30, 99-119.

Mowery D.C., Nelson R.R., Sampat B.N. and Ziedonis A.A. (2004). "The Ivory Tower and Industrial Innovation: University-Industry Technology Transfer before and after the Bayh-Dole Act", Stanford University Press, Stanford, California.

Mowery D.C., Sampat B.N. (2001), "University Patents and Patent Policy Debates in the USA, 19251980", Industrial and Corporate Change, 10(3), p. 781-814.

Mowery D.C., Sampat B.N. (2005), Universities in National Innovation Systems, in Fagerberg J., Mowery D.C., Nelson R.R. (eds.) "The Oxford Handbook of Innovation”, Oxford University Press.

National Science Foundation (NSF), 2004, Science and Engineering Indicators (available on line at http://www.nsf.gov/sbe/srs/seind04/start.htm - last visited: March $21^{\text {st }}, 2005$ )

Raymond E. (1999), The Cathedral and the Bazaar: Musings on Linux and Open Source by an Accidental Revolutionary, Cambridge, O’Reilly.

Red Herring (1998), "Chemical Attraction: Long Preferring to Work Independently, Biotech Companies are now Considering the Advantages of Consolidation", May, Issue 54.

Rivette, K.G. and Kline, D. (2000) "Discovering New Value of Intellectual Property", Harvard Business Review, January-February, 54-66.

Rivette, K.G., Kline, D. (1999), Rembrandt In The Attic: Unlocking the Hidden Value of Patents, Harvard Business School Press, Boston, MA.

Saint-Paul G. (2001), "Growth effects of non-proprietary innovation”, CEPR Discussion Paper Series No. 3069, http://cepr.org/pubs/dps/DP3096.asp.

Salter A., D'Este P., Pavitt K., Scott A., Martin B., Geuna A., Nightingale P., Patel P., Talent, Not Technology: The Impact of Publicly Funded Research on Innovation in the UK, SPRU Science and Technology Policy Research, University of Sussex, Brighton (UK), 2000.

Scotchmer S. (1991), Standing on the Shoulders of Giants: Cumulative Research and the Patent Law, Journal of Economic Perspectives, 2, 29-41.

Stallman R. (1999), "The GNU Operating System and the Free Software Movement”, in Di Bona C., Ockman S., Stone M. (eds.) (1999), Open Sources: Voices from the Open Source Revolution, O’Reilly: Sebastopol, California.

Teece, D.J. (1986), 'Profiting from Technological Innovation. Implications for integration, collaboration, licensing and public policy', Research Policy, 15(6), 285-305. 
Thursby J.G., Thursby M.C. (2003), Intellectual Property: Enhanced: University Licensing and the Bayh-Dole Act, Science, 301, 1052

Von Hippel E., von Krogh G. (2003), "Open Source Software and the Private-Collective Innovation Model: Issues for Organization Science” Organization Science 14 (2), 209-223.

Von Hippel, E. (1987) “Cooperation between Rivals: Informal Know-How Trading”, Research Policy $16,291-302$.

Walsh J., Arora A., Cohen W. (2003), Research Tool Patenting and Licensing on Biomedical Innovation, in Cohen W., Merrill S. (ed.) Patents in the Knowledge-Based Economy. National Academies Press, Washington DC.

Williamson O. (1975), Markets and Hierarchies: Analysis and Antitrust Implications. Free Press, New York.

Ziedonis R.H. (2004), “Don't Fence Me In: Fragmented Markets for Technology and the Patent Acquisition Strategies of Firms", Management Science, 50(6), June, 804-821. 